\title{
Towards Harmonisation of Construction Industry Payment Legislation: A Consideration of the Success Afforded by the East and West Coast Models in Australia - plus Addendum
}

\author{
Jeremy Coggins, (University of South Australia) \\ Robert Fenwick Elliott, (Barrister and Solicitor of the Supreme Court of South \\ Australia, Partner of Fenwick Elliott Grace, Adelaide)
}

Matthew Bell, (Melbourne Law School, The University of Melbourne)

\begin{abstract}
This article considers the success of the two distinct construction industry payment legislative models operating in Australia - "East Coast" and "West Coast" - in achieving their objective of improving cash flow throughout the construction industry. Success parameters are identified by the authors - namely: the levels of justice afforded by the legislation, the administrative and legal burden generated by the legislation, and the impact of the legislation on the relationships between the contracting parties - which are used as a basis to discuss and compare the performances of the East and West Coast models. It is concluded that the West Coast model provides a more just dispute resolution process, generates less administrative and legal burden, and is more conducive towards establishing positive relationships between contracting parties. However, it is recognised that there is a need for more data to be gathered from construction industry stakeholders before any firm recommendations can start to be made as to the most appropriate conceptual framework and detail for a harmonised approach.
\end{abstract}

\section{Introduction}

Over the past decade construction industry payments legislation (the 'legislation') has been progressively passed on a jurisdiction-by-jurisdiction basis throughout Australia. ${ }^{1}$ The first jurisdiction to pass such legislation was NSW. The NSW Act, based upon the adjudication provisions within the Housing Grants, Construction and Regeneration Act 1996 formed the model upon which most other Australian jurisdictions, to varying degrees, based their legislation, culminating in the Tasmanian Act which received Royal Assent on 17 December 2009. ${ }^{2}$

The current state of construction industry payment legislation throughout Australia, however, is somewhat fragmented, and there have been calls from several commentators for a harmonised national approach (Bailey 2009, Zhang 2009, Bell \& Vella 2010). This paper initially examines the division and inconsistencies which exist in the Australian construction industry payment legislation. A set of success parameters, derived from dispute resolution

\footnotetext{
${ }^{1}$ The relevant legislation, in order of commencement, is: Building and Construction Industry Security of Payment Act 1999 (NSW) - the 'NSW Act', Building and Construction Industry Security of Payment Act 2002 (Victoria) the 'Victorian Act', Building and Construction Industry Payments Act 2004 (Qld) - the 'Qld Act', Construction Contracts (Security of Payments) Act 2004 (NT) - the 'NT Act', Construction Contracts Act 2004 (WA) - the 'WA Act', Building and Construction Industry Security of Payment Act 2009 (Tas) - the 'Tasmanian Act', Building and Construction Industry Security of Payment Act 2009 (ACT) - the 'ACT Act', Building and Construction Industry Security of Payment Act 2009 (SA) - the 'SA Act'. The Acts commenced operation on the following dates: 26 March 2000 (NSW), 31 January 2003 (Vic), 1 October 2004 (QId), 1 January 2005 (WA), 1 July 2005 (NT), 17 December 2009 (Tas). Note that the ACT Act comes into force on 1 July 2010, and the SA Act comes into force on a date which, as at early August 2010, was yet to be proclaimed.

${ }^{2}$ Although the Tasmanian Act commenced operation before the ACT and SA Acts, it was actually the last Act to be passed by Parliament in Australia.
} 
literature, is then proposed as a basis for a subsequent review, comparison and assessment of the key provisions, and performance, of construction industry payment legislation in Australia to date. These parameters include the justice afforded, and the administrative and legal burdens generated, by the legislation.

\section{One Destination, Eight Different Paths}

The common objective of the raft of legislation, apparent from the Second Reading Speeches for each of the Acts, ${ }^{3}$ is to facilitate the flow of cash in a swift manner down the hierarchical contractual chain on construction projects. Thus, the legislation is aimed at "improving payment outcomes for all parties operating in the building and construction industry". 4

\section{The East Coast-West Coast Divide}

The WA and NT legislative models significantly differ from the other Australian Acts in both their underlying conceptual frameworks and in the detail of the drafting which is laid upon them. This has led to the WA and NT Acts, which bear more resemblance to construction industry payments legislation proposed by the Cole Commission Report (2003: Volume 8, Appendix 1) and more in harmony with the legislation passed in the UK and NZ, being distinguished from the other Australian Acts.

Accordingly, the WA and NT Acts have been collectively labelled as the "West Coast" model' legislation as opposed to the "East Coast" model tag given to the other Australian Acts which more closely resemble the NSW Act. ${ }^{5}$

All the Acts comprise common constituent elements including the type of work and contracts covered, the mechanisms for enforcing regular payments and the process for undertaking and enforcing adjudication of disputes arising under the Acts (Bell \& Vella 2010: 575) However, within these common constituent elements, key differences exist between the East and West Coast models. These are broadly summarised as follows:

- $\quad$ The East Coast model Acts provide a detailed statutory payments regime, overriding any inconsistent contractual provisions, which parties undertaking "construction work" or "related goods and services" may choose to engage by submitting a payment claim under the Act at regular intervals and have it responded to within a certain timeframe. Conversely, the West Coast model Acts largely preserve (rather than override) the parties' contractual interim payment regimes.

- The East Coast model Acts only allow for payment claims to be made up the "contractual stream" (typically by a subcontractor against its head contractor, or head contractor against its principal). Conversely, the West Coast model allows for payment claims both up and down the "contractual stream".

- Whilst both models allow for a statutory adjudication scheme to determine, in the interim, ${ }^{6}$ disputed payment claims, they differ with respect to adjudicator appointment, submissions which may be considered by an adjudicator, and the approach which an adjudicator is to adopt in order to arrive at his or her

\footnotetext{
3 ACT (Hargreaves J, 15 October 2009); NSW (lemma M, 29 June 1999); NT (Toyne P, 14 October 2004); Queensland (R E Schwarten, 18 March 2004); SA (Kenyon T, 5 March 2009); Tasmania (Singh L M, 4 November 2009); Victoria (Thomson M R, 21 March 2002); WA (MacTiernan A J, 3 March 2004).

${ }^{4} \mathrm{R}$ E Schwarten MP, in delivering the Second Reading Speech for the Queensland Bill Similarly broad aspirations are expressed in the Second Reading Speeches for each of the other Acts (cited above).

${ }^{5}$ Davenport (2010: 36) has recently described the categories as, respectively, "the UK model" (West Coast) and "the Australian model" (East Coast).

${ }^{6}$ Subject to final determination in arbitration or litigation.
}

Coggins, J et al. (2010) 'Towards harmonisation of construction industry payment legislation: a consideration of the success afforded by the East and West Coast models in Australia', Australasian Journal of Construction Economics and Building, 10 (3) 14-35 
determination. In all of these respects the East Coast Acts are more restrictive (Coggins 2009), disallowing mutual agreement of an adjudicator, consideration of reasons for withholding payment which have not been duly submitted in accordance with the statutory payment scheme, and discouraging an evaluative approach to adjudicators' determinations.

\section{The Devil in the Detail}

Whilst the conceptual divisions between the East and West Coast Acts are readily-apparent, there are many detailed aspects in which the Acts - even those within the same "model" grouping - diverge. These differences are often not revealed without a word-by-word comparison, yet they can make for significant differences in the practical effect of the legislation in different parts of Australia. Indeed, once these disparities are appreciated, industry stakeholders - whether subcontractors challenging a payment schedule outside of their home State or general counsel of national contractors charged with drafting appropriate contractual provisions - may be forgiven for regarding the law as a multi-headed hydra rather than a guardian angel.

Some of these differences are fairly well known, such as the way in which Victoria differs from the other "East Coast" jurisdictions in relation to matters which can be included in a payment claim under the Act (and therefore subject to the Act's default provisions for payment and adjudication) This is discussed in O'Reilly and Stankiewicz (2006), Ridley (2006), Warren \& Thwaites (2007), Redenbach (2007: 102-4). Others are less obvious - for example, the implications of the "counting of days" provisions in the Acts. In the NT, Tasmania, Victoria and WA time continues to run for these purposes through the days between Christmas and the New Year which are not public holidays but comprise the traditional industry shutdown, whereas the ACT, NSW, Queensland and SA Acts expressly exclude this period. ${ }^{7}$

The differences are exemplified by the provisions dealing with the types of arrangements to which the various Acts apply. The starting point for such analysis under the Acts is the definition of "construction work" (or, in Tasmania, "building and construction work"). This is fundamental under each of the relevant Acts because it is contracts for such work, or for "related goods and services", which are "construction contracts" to which the Act applies. ${ }^{8}$

The definition of "construction work" in s 5 of the NSW Act has its origins in section 105 of the UK Act. It reads as follows:

\section{Definition of "construction work"}

(1) In this Act, construction work means any of the following work:

(a) the construction, alteration, repair, restoration, maintenance, extension, demolition or dismantling of buildings or structures forming, or to form, part of land (whether permanent or not)

(b) the construction, alteration, repair, restoration, maintenance, extension, demolition or dismantling of any works forming, or to form, part of land, including walls, roadworks, power-lines, telecommunication apparatus, aircraft runways, docks and harbours, railways, inland waterways, pipelines, reservoirs, water mains, wells, sewers, industrial plant and installations for purposes of land drainage or coast protection,

\footnotetext{
${ }^{7}$ See the definition of "business day" (or, in the NT, "working day") in each Act other than the WA Act. The WA Act uses the term "day" (rather than "business day"), so for the purpose of counting days it is assumed that every day is counted.

${ }^{8}$ See ACT Act: Dictionary and ss 7-9; NSW Act ss 4-7; NT Act ss 5-7 and 9; Queensland Act ss 3 and 10-11 and Sch 2; SA ss 4-7; Tasmanian Act ss 4-7; Victorian Act ss 4-7; WA Act ss 3-5 and 7. General commentary on these definitions (albeit written prior to the passage of all of the Acts) is provided in, eg, Jacobs (2010: 42-4 \& 489; Davenport (2004: 27-29).
}

Coggins, J et al. (2010) 'Towards harmonisation of construction industry payment legislation: a consideration of the success afforded by the East and West Coast models in Australia', Australasian Journal of Construction Economics and Building, 10 (3) 14-35 
(c) the installation in any building, structure or works of fittings forming, or to form, part of land, including heating, lighting, air-conditioning, ventilation, power supply, drainage, sanitation, water supply, fire protection, security and communications systems,

(d) the external or internal cleaning of buildings, structures and works, so far as it is carried out in the course of their construction, alteration, repair, restoration, maintenance or extension,

(e) any operation which forms an integral part of, or is preparatory to or is for rendering complete, work of the kind referred to in paragraph (a), (b) or (c), including:

(i) site clearance, earth-moving, excavation, tunnelling and boring, and

(ii) the laying of foundations, and

(iii) the erection, maintenance or dismantling of scaffolding, and

(iv) the prefabrication of components to form part of any building, structure or works, whether carried out on-site or off-site, and

(v) site restoration, landscaping and the provision of roadways and other access works,

(f) the painting or decorating of the internal or external surfaces of any building, structure or works,

(g) any other work of a kind prescribed by the regulations for the purposes of this subsection.

(2) Despite subsection (1), construction work does not include any of the following work:

(a) the drilling for, or extraction of, oil or natural gas,

(b) the extraction (whether by underground or surface working) of minerals, including tunnelling or boring, or constructing underground works, for that purpose,

(c) any other work of a kind prescribed by the regulations for the purposes of this subsection.

Turning to the other East Coast Acts, most follow the NSW definition closely:

- the ACT provision (s 7) is substantially identical to the NSW provision but has been reformatted;

- the Queensland provision (s 10) is identical to the NSW save for some minor wording and syntax changes and the express inclusion (via a new sub-section (1)(g)) of the testing of soils and road making materials;

- the South Australian provision (s 5) likewise makes minor wording changes but its only substantive amendment is expressly to include fencing in sub-section (1)(e); and

- the Victorian provision (s 5) is identical to the NSW.

However, the Tasmanian provision (s 5 ) has been reformatted and re-worded significantly. It incorporates most of the elements of the other East Coast provisions but with many alterations in terminology (for example, "docks and harbours" has been replaced by "marine infrastructure" and "power lines" has been replaced by "energy infrastructure").

Moreover, a number of matters have been expressly included within the ambit of the Tasmanian Act; for example, structures supporting agricultural, horticultural or forestry products (Section 5(1)(a)(vi)), or allowing access to certain types of activities (Section $5(1)(a)(v i i))$. Matters which have been added to those covered by the "fittings" (here, "systems or services") provision (sub-section (1)(c)) include passenger and goods lifts (Section 5(1)(c)(iii)) and plumbing installations (Section 5(1)(c)(iii)). On the other hand, drainage, sanitation and water supply have disappeared from that list of examples.

The gulf, noted above, between the East and West Coast Acts in underlying intent and drafting scheme is reflected in the definition of "construction work" in the WA and NT Acts. Whilst there is much that is compatible in the ultimate effect of the provisions, there are also

Coggins, J et al. (2010) 'Towards harmonisation of construction industry payment legislation: a consideration of the success afforded by the East and West Coast models in Australia', Australasian Journal of Construction Economics and Building, 10 (3) 14-35 
significant differences. Moreover, a detailed comparison of the Acts is necessary in order to ascertain whether a particular activity falls within or outside the scope of the Act. ${ }^{9}$

Turning first to the types of work which $-{ }^{10}$ subject to the exclusions noted below $-{ }^{11}$ fall within the definition, the West Coast Acts are, in fact, wider in ambit than those of the East Coast. This is due, primarily, to the express mention of:

- work relating to reclaiming, draining, or preventing the subsidence, movement or erosion of, land: $;^{12}$ and

- off-shore construction of civil works and buildings (whereas, under the East Coast Acts, works need to be "forming, or to form, part of the land"). ${ }^{13}$

Having said that, there are also significant differences between the West and East Coast Acts in respect of activities which are excluded. These are perhaps best understood by using $\mathrm{s} 5$ of the NSW Act (set out above) as a base: ${ }^{14}$

- the drilling and extraction exclusion in respect of oil and natural gas extends, under the NT and WA Acts, to drilling for the purposes of discovery of such materials; ${ }^{15}$

- in respect of the minerals exclusion, the NSW Act refers to their "extraction (whether by underground or surface working)... including tunnelling or boring, or constructing underground works, for that purpose", ${ }^{16}$ whereas the NT and WA Acts:

- exclude "constructing a shaft, pit or quarry, or drilling, for the purposes of discovering or extracting any mineral bearing or other substance"; ${ }^{17}$

- do not expressly exclude the process of extraction of minerals; and

- also do not expressly exclude tunnelling or boring - indeed, these are expressly mentioned in the inclusions sub-section; ${ }^{18}$

- the WA Act (but not the NT Act) ${ }^{19}$ excludes both sub- and above-surface plant, through its broadly-framed reference to "constructing any plant for the purposes of extracting or processing oil, natural gas or any derivative of natural gas, or any mineral bearing or other substance"; ${ }^{20}$

\footnotetext{
${ }^{9}$ Whilst this paper does not purport to provide such an analysis, it is noted, for example, that the West Coast Acts use a separate definition of "civil works" (NT Act s 4; WA s 4(1)) to provide an expanded listing of the infrastructure works referred to in sub-s (1)(b) of the East Coast Acts.

${ }^{10}$ NT Act s 6(1); WA Act s 4(2).

${ }_{11}^{11}$ NT Act s 6(2); WA Act s 4(3).

12 NT Act s 6(1)(a); WA Act s 4(2)(a). Having said that, the reference to "coast protection" in sub-s (1)(b) of the East Coast Acts may be expected to cover certain of these activities.

${ }_{13}^{13}$ NT Act s 6(1)(c); WA Act s 4(2)(c). The East Coast wording is in sub-s (1)(b).

${ }^{14}$ It should be noted, generally, that each of these exclusions (other than that in respect of watercraft - see $n 24$ below) is subject to the relevant work being on a site in the NT or WA (as applicable) whereas there is no such territorial restriction in the East Coast Acts.

${ }_{15}$ NSW Act s 5(2)(a); NT Act s 6(2)(a); WA Act s 4(3)(a).

${ }^{16}$ NSW Act S 5(2)(b).

${ }^{17}$ NT Act s 6(2)(b); WA Act s 4(3)(b). No express guidance is given as to the ambit of "other substance".

${ }^{18}$ NT Act s 6(1)(f)(i); WA Act s 4(2)(f)(i). It may, however, be expected that tunnelling and boring will usually fall outside the ambit of "construction work" either through the "constructing..." exclusion referred to in the first subpoint above or because mining is not an activity referred to in the inclusions sub-section;

${ }^{19}$ The difference is acknowledged in the Second Reading Speech for the NT Act (Toyne, n 5 above) but no commentary is provided upon it. However, by adopting the WA Act drafting scheme but leaving out its paragraph (c), the NT Act does not incorporate the exclusion of underground works which is found in paragraph (b) of the East Coast Act exclusions. Moreover, though s 6(2)(d) allows for other work to be excluded by Regulation, there is no such provision in the Construction Contracts (Security of Payments) Regulations 2005, the only Regulations which (as of April 2010) have been made under the NT Act. Thus, whether such is the intent or not, the Northern Territory is the only place in Australia where the construction of underground works is covered by the security of payment Act.

${ }^{20}$ WA Act s 4(3)(c).
}

Coggins, J et al. (2010) 'Towards harmonisation of construction industry payment legislation: a consideration of the success afforded by the East and West Coast models in Australia', Australasian Journal of Construction Economics and Building, 10 (3) 14-35 
- the NT and WA Acts have carried through the UK Act exclusion in relation to wholly artistic works, albeit in modified terms; ${ }^{21}$ and

- the NT and WA Acts specifically exclude "constructing the whole or any part of watercraft". 22

\section{Does Inconsistency Hamper Economic Efficiency?}

The "construction work" analysis in the previous section is but one example of how the various Australian Acts' approaches are far from consistent. It also demonstrates that ascertaining such a basic matter as whether a particular activity is covered by the scheme demands a painstaking and time-consuming legal analysis. Such inconsistency and lack of accessibility seems, at the very least, to run counter to the desire to achieve for the industry "a fast, cheap, non-legalistic way of resolving payment for work done or material or services supplied". ${ }^{23}$

The inefficiencies inherent in such a situation are readily apparent. It has been observed, for example, that detailed regimes for inclusions and exclusions from the legislative scheme tend to lead to uncertainty and court intervention (Constable 2006). ${ }^{24}$ In the early years of the UK Act's operation, for instance, there were many attempts to run the "fallacious" argument that, wherever a power generation plant was included within a construction project, the entirety of the project was excluded from the ambit of the Act by dint of the "power generation" carve-out in s 105(2)(c)(i) (Coulson 2007:35). ${ }^{25}$

More fundamentally, any such scheme of inclusions and exclusions - and, especially, one which applies in markedly inconsistent ways across the nation - exposes the issue of whether the legislation does, in fact, represent a worthy reform for the industry. For His Honour Judge Humphrey Lloyd (as he then was), commenting upon the UK Act in 2001, the related underlying questions included:

if adjudication is such a good idea, why does it not apply to all sectors of the construction industry?... If it is a good idea but it is not needed in the well-managed and harmonious parts of the industry then why go to the trouble of such convoluted exceptions - if there will be no need to have recourse to adjudication then there need be no exemptions. Will those working there have anything to worry about? If they are concerned then what troubles them? Is reform in fact needed? (Lloyd 2001: 450) ${ }^{26}$

These are issues which go to the heart of the legislation both as enacted and as it may be reformed. Debate upon these questions is, however, hampered by there being little explicit guidance provided by the legislatures as to why the inclusions and exclusions are defined as they are. In the British context, Judge Coulson has noted that there was significant criticism within the UK Parliament of the UK Act's scheme of exclusions - one MP proposed, for example, that "[t]here is no more reason to exclude the process industries than to exempt drivers who have never had an accident from obeying the Highway Code". ${ }^{27}$

\footnotetext{
${ }^{21}$ NT Act s 6(2)(c); WA Act s 4(3)(d).

${ }^{22}$ NT Act s 6(3); WA Act s 4(4).

${ }^{23}$ Victorian Building Commission introduction to the Victorian Act, at www.buildingcommission.com.au.

${ }^{24}$ Commenting upon the debates within the British Parliament in relation to the listing of included and excluded contracts, His Honour Judge Peter Coulson QC (Coulson 2007: 27) noted that "[i]t is difficult not to feel instinctive sympathy with those who pointed out... that these definitions were likely to lead to just the sort of disputes that the Act itself was designed to avoid."

${ }^{25} \mathrm{His}$ Honour summarises these cases at pp 35-6 and their resolution of the issue by reference to identification of the "primary activity" within the site.

${ }^{26}$ See, similarly, Coulson 2007: 9-10.

27 Peter Thurnham, MP (House of Commons, 8 July 1996), cited at Coulson 2007: 10-11.
}

Coggins, J et al. (2010) 'Towards harmonisation of construction industry payment legislation: a consideration of the success afforded by the East and West Coast models in Australia', Australasian Journal of Construction Economics and Building, 10 (3) 14-35 
Despite such misgivings, the lengthy list of included and excluded "construction operations" was carried through into the UK Act (and, as noted above, has formed the basis for the various Australian Acts' approaches). Likewise, the Second Reading speeches for the WA and NT Acts provide no guidance as to why, for example, the exclusions from the ambit of "construction work" are substantially different from those of the NSW Act which preceded them.

Doubtless there are reasons which the relevant Parliaments found compelling as to the extent to which legislative intervention is needed, especially within the WA process plant, mining and oil and gas industries. However, without explicit guidance as to the policy intent, the reform process as carried into law in each State and Territory is left open to the criticism that it simply reflects the inevitable tendency, identified by Davenport (2006: 21), for a "competition between various vested interests". ${ }^{28}$

\title{
Towards Harmonisation
}

Few in the industry would seriously advocate that the present, disjointed situation ought to continue; rather, there have been increasing calls - echoing those of the Cole Royal Commission (Cole 2003) nearly a decade ago - to forge a uniform national approach to security of payment regulation (Bailey 2009, Zhang 2009, Bell \& Vella 2010). Marcus Jacobs QC (Jacobs 2007: 16), for example, has observed that:

\begin{abstract}
[i]t must be a matter of considerable confusion to practitioners advising clients who have projects in more than one State/ Territory where there is so little uniformity in the comparative legislation.... The sooner there is uniform legislation in a relatively small country such as Australia, the better for the construction industry.
\end{abstract}

The key question at this stage is how such an approach might be achieved, especially given the lack of consensus as reflected in both the statutes and their interpretation by the Courts.

It is suggested that one approach or step towards achieving harmonisation and consensus is to review and assess the performance of the existing legislative schemes to date, such that the most successful legislative aspects may be identified for adoption into a unified model. However, such an approach is not straightforward as the identification of parameters of success vis à vis the operation of the legislation is likely to be contentious and, of itself, would require general consensus for such an approach to be effective.

Nevertheless, in order to initiate debate as to the performance of existing legislative schemes in the interests of identifying the most desirable characteristics for a harmonised model, the remainder of this article aims to review, compare and assess the provisions and performance of the two Australian legislative models - East Coast and West Coast - against key parameters of success identified by the authors. Such an approach will assist in revealing observed strengths and weaknesses in the enacted legislative models, with a view to informing an approach to national harmonisation. Further, observations with respect to provisions of construction industry payments legislation enacted outside of Australia ${ }^{29}$ will be

\footnotetext{
${ }^{28}$ Reflecting this, of the eight Second Reading Speeches referred to in n 5 above, six noted expressly that industry groups (whether state- or nationally-based) offered views which led to the relevant Act being put forward, but only one - that of Tasmania - referred to the desire to align conditions with those in other jurisdictions. Having said that, "benefit[ting] building and construction firms with national or interstate operations by improving consistency between payment regimes across all three jurisdictions" was mentioned in the Second Reading Speech for the 2006 Bill amending the Victorian Act (M R Thomson MP, 15 June 2006).

${ }_{29}$ The UK Act, Construction Contracts Act 2002 (NZ) - the 'NZ Act', and Building and Construction Industry Security of Payment Act 2004 (Singapore) - the 'Singapore Act'. Moreover, there are moves afoot in Ireland and Malaysia to introduce legislation similar to the UK Act: respectively, the Construction Contracts Bill 2010 was presented to the Seanad Éireann on 12 May 2010 and a preliminary draft of the Malaysian Construction Industry Payment and Adjudication Act was published in 2009 and is available at www.cidb.gov.my.
}

Coggins, J et al. (2010) 'Towards harmonisation of construction industry payment legislation: a consideration of the success afforded by the East and West Coast models in Australia', Australasian Journal of Construction Economics and Building, 10 (3) 14-35 
made where such reference may contribute towards optimal harmonisation of the legislation in Australia.

\section{Key Success Parameters}

To date, performance of existing construction industry payments legislation in Australia has been monitored in the form of quantitative statistical data collated by the relevant administering government departments, or agencies, in each jurisdiction. ${ }^{30}$ This statistical data collates such information as number of adjudication applications made and total values of adjudicated payment claims and determinations each year. The data shows that, to varying degrees in each jurisdiction, the legislation is achieving its objective of improving cash flow within the construction industry as the number and total value of payment claims determined in adjudication has increased annually. This increase has been particularly marked in NSW and Queensland where, by $2008 / 09$, the number of annual adjudication applications in each jurisdiction had reached approximately 1000 , and total value of payment claims in adjudication approximately $\$ 200$ million. ${ }^{31}$ In WA there were 105 adjudication applications ${ }^{32}$ made in 2008/09 and a total value of payment claims in adjudication of approximately $\$ 36$ million (Construction Contracts Registrar 2009).

The significant take-up rates of statutory adjudication in NSW and Queensland have led to observations that the payments legislation in these jurisdictions has been effective in resolving disputes of all sizes. ${ }^{33}$ Accordingly, Riddell (2009: 1) observed that:

The security of payment legislation, particularly in New South Wales and in Queensland, appear to have been remarkably successful in achieving its object of ensuring that a person who undertakes construction work or provides related goods and services is entitled to receive and is able to recover progress payments.

Whilst such data indicates a significant uptake of statutory adjudication and resultant flow of cash in the construction industry over the relatively short time the legislation has been enacted, it is contended that to draw any conclusions as to overall longer term legislative success based solely upon such data would be imprudent and misleading. It is proposed that such longer term success is predicated upon continued satisfaction of all stakeholders in the construction industry with the legislation's payment and adjudication schemes. Therefore, it is argued that there are several other parameters which must be considered in assessing the success of the legislation in meeting its objective of achieving sustained improvement of cash flow throughout the construction industry. These parameters include the levels of justice afforded by the statutory scheme, the consequential costs of the legislative scheme to the construction industry both in terms of administrative and legal burden generated, and the impact of the legislation (positive or negative) on the relationships between the contracting parties. ${ }^{34}$

\footnotetext{
${ }^{30}$ NSW Procurement Division, Department of Services, Technology and Administration; Building Commission Victoria; Building and Construction Industry Payments Agency (Qld); Building Management \& Works Division, Department of Treasury and Finance (WA); and, Department of Justice (NT).

${ }_{31}$ More accurately, as reported by Building \& Construction Industry Payments Agency (2009) and NSW Procurement (2009): 940 adjudication applications in NSW during the 2008 calendar year and 999 adjudication applications in Queensland during the 2008/09 financial year; and, $\$ 187,034,897$ claimed in adjudication in NSW during the 2008 calendar year and $\$ 234,564,850$ claimed in adjudication in Queensland during the 2008/09 financial year.

${ }^{32}$ However, it must be remembered that the population of WA is only 2.56 million compared with 4.45 million in Queensland and 7.17 million in NSW (Population data sourced from Australian Bureau of Statistics (ABS), Australian Demographic Statistics, September Quarter 2009 available on ABS website <http//:www.abs.gov.au>). ${ }^{33}$ See Building \& Construction Industry Payments Agency 2009: 6; and, NSW Procurement 2009: 4.

${ }^{34}$ It is notable that the UK legislation followed the report of Sir Michael Latham (Latham 1993). That report emphasised the importance of dispute resolution systems on the crucial ingredient of trust within the construction process.
}

Coggins, J et al. (2010) 'Towards harmonisation of construction industry payment legislation: a consideration of the success afforded by the East and West Coast models in Australia', Australasian Journal of Construction Economics and Building, 10 (3) 14-35 
These parameters encapsulate three of the criteria identified by Ury, Brett \& Goldberg (1988: 11) in their seminal textbook on dispute resolution, used for comparing the different approaches to resolution of disputes: transaction costs, ${ }^{35}$ satisfaction with outcomes (of which justice in outcome and process is a key component), and recurrence of disputes. Ury, Brett \& Goldberg (1988: 12) noted that these criteria are interrelated in that dissatisfaction with outcomes contributes to recurrence of disputes, ${ }^{36}$ which in turn increases transaction costs.

Accordingly, therefore, it is suggested that an unsustainable dispute resolution process is characterised by stakeholder dissatisfaction with outcomes, a relatively high proportion of recurring disputes and relatively high transaction costs. Conversely, a sustainable dispute resolution process is characterised by stakeholder satisfaction with outcomes, a relatively low proportion of recurring disputes and low transaction costs. In particular, a dispute resolution process that enables a high degree of trust between contracting parties will encourage an effective and efficient industry, and vice-versa.

\title{
Justice in Dispute Resolution
}

A linchpin of all the legislation is the interim resolution of payment claim disputes via a mandatory adjudication scheme. This scheme represents a dispute resolution method or process which, in the context of construction payment claims disputes, may be considered as an integral component of an overall dispute resolution system - this system being a multistepped series of dispute resolution methods which may typically involve negotiation, adjudication, arbitration and/or litigation. Much has been written in the field of dispute system design with respect to the significance of justice in the evaluation of dispute resolution systems. An initial overview of key points arising from this literature provides a useful basis to inform a subsequent analysis of justice afforded by each the statutory adjudication schemes under the East and West Coast models.

Many varieties of justice have been identified in connection with dispute resolution (see, for example: Bingham 2008). Of these, substantive and, in particular, procedural justice are most often cited as impacting upon satisfaction with dispute resolution systems. According to Ury, Brett \& Goldberg (1988: 12):

\begin{abstract}
Satisfaction [with a dispute resolution process] may also depend on whether the disputant believes that the resolution is fair. Even if an agreement does not wholly fulfil her interests, a disputant may draw some satisfaction from the resolution's fairness.
\end{abstract}

Substantive, or distributive, justice essentially refers to the fairness of the outcome produced by a decision process. Procedural justice refers to the justice of the processes or methods used to arrive at distributive justice.

Procedural justice recognises that a disputant's satisfaction with a method or system of dispute resolution is a function of process rather than outcome. Several authors have identified procedural justice as integral to satisfaction with a dispute resolution process (Ury, Brett \& Goldberg 1988: 12; Constantino \& Sickles Merchant 1996: 173; Susskind \& Cruikshank 1987: 24). Further, the perception of a fair process has been acknowledged to be as important as the reality of impartiality (Bingham 1997: 215). There is some consensus that if disputants believe that the dispute resolution process has been fair they may be more willing to accept decisions (Tyler 2000 as seen in Van Veen, Kreutzwiser \& de Loë 2003),

\footnotetext{
${ }^{35}$ Defined by Ury, Brett \& Goldberg (1988: 11) as "the time, money, and emotional energy expended in disputing, the resources consumed and destroyed, and the opportunities lost.

${ }^{36}$ In the case of statutory adjudication, recurrence of disputes may take the form of an application to the courts to have the adjudicator's determination rendered void, or the referral of an adjudicated payment dispute to a final dispute resolution process such as arbitration or litigation.
}

Coggins, J et al. (2010) 'Towards harmonisation of construction industry payment legislation: a consideration of the success afforded by the East and West Coast models in Australia', Australasian Journal of Construction Economics and Building, 10 (3) 14-35 
and that a sense or perception of procedural justice may be as, or more, important than the outcome (Ury, Brett \& Goldberg 1988: 12; Lind, EA, \& Tyler, TR 1988: 85 \& 95). De Cremer and van Knippenberg (2003: 8) suggest that procedural justice becomes especially important to disputants when outcomes are unfavourable to them.

With respect to evaluating procedural fairness of dispute resolution processes, the following questions have been raised as pertinent:

- Were all the groups who wanted to participate given an adequate chance to do so? (Susskind \& Cruikshank 1987: 24)

- Was everyone given an opportunity to express his or her views? (Susskind \& Cruikshank 1987: 24; and Ury, Brett \& Goldberg 1988: 12 \& 33)

- How much were the disputants able to participate in shaping the settlement? (Ury, Brett \& Goldberg 1988: 12 \& 34)

- Did the disputants believe that the third party, if there was one, acted fairly? (Ury, Brett \& Goldberg 1988: 12 \& 37)

\section{A Consideration of Justice in the East and West Coast Legislation}

Key differences exist between the East and West Coast models with respect to the payment and adjudication schemes provided. These differences impact upon the measures of procedural and substantive justice afforded by each model.

\section{Payment Systems}

The East Coast model operates a "dual payment" system for progress payment claims, creating a statutory payment system which runs alongside any contractual regime. ${ }^{37}$ In order to engage the statutory payment system, a claimant must endorse its payment claim as being made under the Act ${ }^{38}$ and serve it upon the respondent. ${ }^{39}$ The West Coast model does not operate a dual payment system, but rather payment claims referred to in the Act are those made under the contractual regime. Thus, a claimant under the East Coast model may only avail itself of the Act's dispute resolution processes if it endorses its progress payment as being made under the Act. This endorsement requirement is a potential barrier to procedural justice in the East Coast model, as a contractor or supplier may deliberately refrain from endorsing its payment claim through fear of negative repercussions ${ }^{40}$ in its relationship with the principal. This effectively denies such a contractor or supplier access to the dispute resolution process available under the Act.

Indeed, a 2007 survey carried out by Brand \& Uher (2010: 17), which sought to assess the performance of the NSW Act by surveying the members of two peak trade associations operating in NSW, found that around half of the sampled contractor and subcontractor firms felt that endorsement of payment claims negatively affects to some degree the working relationship between the parties to a payment claim. ${ }^{41}$ Conversely, under the West Coast model, there is no such scope for a party to be deterred from accessing the Act's dispute resolution process as statutory adjudication is available merely on the basis of a dispute having arisen on a contractual payment claim. ${ }^{42}$

\footnotetext{
${ }^{37}$ Beckhaus v Brewarrina Council [2002] NSWSC 960 per Macready AJ at [60]. Such a dual payment system was described as a "dual railroad track system" by Macready AJ in Transgrid $v$ Siemens \& Anor [2004] NSWSC 87 at [56].

38 See s 13(2)(c) of the NSW Act.

${ }^{39}$ See $\mathrm{s} 13(1)$ of the NSW Act.

${ }^{40}$ Such as, in its most extreme form, being "blacklisted" by the principal with respect to being offered work on future contracts.

${ }^{41}$ Nevertheless, the same survey showed that about two-thirds of respondent firms either "always" or "usually" endorse payment claims as being made under the Act - Brand \& Uher 2010: 16.

${ }^{42}$ Under the West Coast model, either party may apply for adjudication of a payment dispute within 28 days after the dispute arises (see s 26(1) of the WA Act). A payment dispute arises if by the time when the amount claimed

Coggins, J et al. (2010) 'Towards harmonisation of construction industry payment legislation: a consideration of the success afforded by the East and West Coast models in Australia', Australasian Journal of Construction Economics and Building, 10 (3) 14-35
} 


\section{Scope of Payment Claims}

The East Coast model provides for recovery of progress payments only and, therefore, its dispute resolution processes may only be used by a contractor or supplier to recover payment from a principal, i.e., "upstream" claims. Herein lies another potential barrier to procedural justice in the East Coast model, as the judiciary has allowed claimants to recover amounts for delay damages in adjudicated payment claims under the Act. ${ }^{43}$ This, as Davenport (2007: 14) puts it, creates an "imbalance" as only one party is allowed to apply for adjudication of payment disputes regarding damages. As claims for damages falling within the scope of the contract have the potential to be made by either contractual party, ${ }^{44}$ it would appear to be blatantly unfair to allow only one party the right to refer such claims to the Act's dispute resolution processes.

No such injustice exists in the West Coast model. The scope of the West Coast model is wider, providing the right for either party to make an adjudication application in relation to any payment disputes falling within the scope of the building contract, including debts and damages claims (see s 25 of the WA Act).

\section{Right to Defend a Payment Claim}

Under the East Coast model's statutory payment regime, a respondent has up to 10 business days ${ }^{45}$ after the payment claim is served to serve a payment schedule indicating the amount of the payment it proposes to make. If the scheduled amount is less than the claimed amount, the schedule must indicate why the scheduled amount is less with reasons for withholding payment (see s 14(3) of the NSW Act). If the respondent either schedules an amount less than the payment claim or fails to pay the whole or part of the scheduled amount by the due date, the claimant may make an adjudication application under the Act ( $\mathrm{s}$ $17(1))$

In the case where a claimant disputes a lesser amount that has been scheduled and paid, the claimant must serve an adjudication application on an Authorised Nominating Authority (ANA) of its choice (s 17(3)(b) of the NSW Act) with a copy served on the respondent (s $17(5))$ within 10 business days $s 17(3)(c)$ after receiving the payment schedule. ${ }^{46}$ The respondent then has either a period of 5 business days ${ }^{47}$ after receiving a copy of the application or 2 business days ${ }^{48}$ after receiving notice of an adjudicator's acceptance of the application, whichever is the later, to lodge an adjudication response with the adjudicator. ${ }^{49}$

If the respondent does not duly provide a payment schedule, it becomes liable to pay the claimed amount to the claimant on the due date for the progress payment (s 14(4)(b) of the NSW Act). Where no payment schedule is provided, the claimant has two paths available under the Act by which to recover the payment claim.

The first path is for the claimant to seek summary judgment in court for the debt due (s $15(2)(a)(i)$ of the NSW Act), in which case the respondent is not entitled to bring any cross-

in a payment claim is due to be paid under the contract, the amount has not been paid in full, or the claim has been rejected or wholly or partly disputed (see s 6(a) of the WA Act).

${ }^{43}$ See Coordinated Construction Co Pty Ltd V JM Hargreaves Pty Ltd [2005] NSWCA 228; Coordinated Construction Co Pty Ltd v Climatech (Canberra) Pty Ltd \& Ors . [2005] NSWCA 229; Minister for Commerce (formerly Public Works \& Services) v Contrax Plumbing (NSW) Pty Ltd \& Ors [2005] NSWCA 142; and, John Holland Pty Limited $v$ Roads \& Traffic Authority of New South Wales \& Ors [2007] NSWCA 19.

${ }^{44} \mathrm{Eg}$, contractors' claims for delay and disruption costs caused by principals, and principals' claims for liquidated or general damages for contractor's delay in achieving practical completion.

45 Except in the SA Act which allows 15 business days - see s 14(4)(b)(ii) of the SA Act.

${ }^{46}$ Except in the SA Act which allows 15 business days - see $s$ 17(3)(c) of the SA Act.

${ }^{47}$ Except in the Tasmanian Act (7 business days) and ACT Act (10 business days).

${ }^{48}$ Except in the Tasmanian Act ( 5 business days) and ACT Act ( 5 business days).

${ }^{49}$ See s 20(1) of the NSW Act.

Coggins, J et al. (2010) 'Towards harmonisation of construction industry payment legislation: a consideration of the success afforded by the East and West Coast models in Australia', Australasian Journal of Construction Economics and Building, 10 (3) 14-35 
claim against the defendant in the summary judgment proceedings, or raise any defence in relation to matters arising under the construction contract (s 15(4)(b) of the NSW Act). The second path is for the claimant to apply for the payment claim to be determined in adjudication, ${ }^{50}$ in which case the respondent will be disallowed from lodging an adjudication response (s 20(2A) of the NSW Act), effectively denying the respondent any voice during the adjudication $^{51}$ as an adjudicator is essentially limited to a consideration of the submissions duly made by the parties ${ }^{52}$ when determining an adjudication(s $22(2)$ of the NSW Act).

Even in circumstances where the respondent has duly served a payment schedule, it may only include in its adjudication response reasons for withholding payment which have previously been included ${ }^{53}$ in the payment schedule (s 20(2B) of the NSW Act). Thus, a respondent may be prevented from being able to present its full case to the adjudicator unless it has previously served a comprehensive payment schedule which covers all the issues it may wish to rely on subsequently. Indeed, $41 \%$ of adjudication applications in Queensland to date for the 2009/10 financial year have been made on the basis that the respondent has failed to duly serve a payment schedule ${ }^{54}$ on the claimant (Building and Construction Payments Agency 2010).

These highly restrictive provisions with regards to payment schedules and adjudication responses have a major impact upon considerations of procedural and substantive justice. Failure to duly serve a payment schedule not only strips the respondent of any right to subsequently defend the payment claim, but may also potentially result in a gross miscarriage of substantive justice or, at the very least, an outcome which is not perceived as fair by the respondent. ${ }^{55}$

It is difficult to conceive of any fair and respected dispute resolution process denying the right for one of the parties to put forward their arguments or, at the very least, to be heard. Indeed, it is a fundamental right of most dispute resolution processes that both parties have the right to present their case. ${ }^{56}$ Lack of opportunity for the respondent to present its case, together with the consequent likelihood of a determination perceived as unjust by the respondent, would seem to be a recipe for respondent dissatisfaction with the dispute

\footnotetext{
${ }^{50}$ If the claimant chooses this path, it must notify the respondent of its intention to apply for adjudication of the payment claim, and allow the respondent a second opportunity to serve a payment schedule within 5 business days from the date of such notification - see s 17(2) of the NSW Act.

51 This second path may be preferable to some claimants in terms of speed of recovery as the claimant may request an adjudication certificate from the relevant ANA stating the adjudicated amount (see s 24 of the NSW Act) and file the adjudication certificate as a judgment for a debt in any court of competent jurisdiction (see $s 25$ of the NSW Act).

${ }^{52}$ le, payment claim, payment schedule and all submissions that have been duly made in their support.

${ }^{53}$ Furthermore, whilst a respondent cannot include in its adjudication response a reason for withholding payment not included in its payment schedule, it has been held in Minister for Commerce (formerly Public Works \& Services) v Contrax Plumbing (NSW) Pty Limited [2005] NSWCA 142 per Hodgson JA at [37] that a claimant can raise reasons its adjudication application to substantiate entitlement to payment even though such reasons were not included in its payment claim, provided that such reasons are by way of response to arguments raised by the respondent in its payment schedule.

${ }^{54}$ Such failure may be due to the potentially massive administrative task which a contractor may face of preparing dozens of payment schedules each month, or due to inadequate knowledge of the Act by the respondent. Accordingly, a survey of contractors and subcontractors in the NSW construction industry carried out by Brand \& Uher (2010) showed that $49 \%$ had either low or no personal knowledge of the NSW Act and $38 \%$ had only moderate knowledge of the NSW Act.

${ }^{55}$ For example, in Walter Construction v CPL [2003] NSWSC 266, the builder submitted a payment claim for $\$ 14.9$ million under the NSW Act. The owner principal failed to provide a payment schedule and, therefore, became liable for the full amount of the payment claim even though the contract superintendent subsequently certified a payment of $\$ 952,351$. The claimant builder successfully obtained summary judgment for the full amount of the payment claim despite several reasons put forward by the owner to avoid summary judgment.

${ }^{56}$ For example, Article 18 of the United Nations Commission on International Trade Law (UNCITRAL) Model Law on International Commercial Arbitration embodies the basic principle that the parties shall be treated with equality and each party shall be given a full opportunity of presenting its case.
}

Coggins, J et al. (2010) 'Towards harmonisation of construction industry payment legislation: a consideration of the success afforded by the East and West Coast models in Australia', Australasian Journal of Construction Economics and Building, 10 (3) 14-35 
resolution processes provided by the East Coast model. The scores of applications by adjudication respondents to the NSW courts over the past decade to have adjudicators' determinations rendered void for a multitude of reasons ${ }^{57}$ are, perhaps, indicative of such levels of dissatisfaction and perceptions of procedural and substantive injustice.

If Australia were a signatory to the European Convention on Human Rights, it would warrant serious consideration as to whether the East Coast Model may be struck down as offensive. ${ }^{58} \mathrm{~A}$ number of decisions of the European Court of Human Rights on compulsory ADR processes take the same general line: that signatory states should be given some latitude to make their own laws, but subject to some minimum safeguards, and in particular on the basis of an adequate opportunity for both parties to be heard. It is on this point that statistics show that the East Coast Model very frequently fails. The point is hypothetical ${ }^{59}$ but if several Australian states were found to have failed to meet these international jurisprudential standards it would be bound to have some negative impact on Australia's standing generally in the area of international law.

Unlike the East Coast model, the West Coast model provides no detailed statutory payment system but rather gives primacy to the parties' agreed contractual payment regime. ${ }^{60}$ The West Coast legislation does not make the serving of a response to the payment claim $^{61} \mathrm{a}$ condition precedent to the right of a party who is served with an adjudication application ${ }^{62}$ to lodge an adjudication response. Additionally, there are no limitations as to the inclusion of reasons for withholding payment in a response to an adjudication application. Thus, providing that a party lodges their response to an adjudication application within the time allowed by the legislation, ${ }^{63}$ it will not be deprived of the opportunity to present its full case. This would appear to be a far more satisfactory approach in terms of achieving procedural and substantive justice in the dispute resolution process.

Furthermore, an adjudicator under the West Coast legislation is not restricted to a consideration of documents submitted by the parties when making his or her determination as in the East Coast model. ${ }^{64}$ Rather, the legislation encourages a West Coast adjudicator to be more evaluative in their approach to determination by providing that an adjudicator "is not

\footnotetext{
57 The NSW Supreme Court has handed down at least 210 judgments, and the NSW Court of Appeal 41 judgments, in relation to issues concerning the NSW Act since 2001. These judgments are listed on the Contract Administration Group's

website <http://www.contraxgroup.com/showjudgments.asp?area=1\&section=1\&subsection=57\&state=2>

${ }^{58}$ One of the authors raised the point at a lunch table in London consisting of senior construction lawyers; the view was unanimous that the East Coast model would be declared unlawful. In Austin Hall v Buckland Securities Ltd [2001] EWHC Technology 434, the court refused to declare the UK adjudication regime unlawful, but then logic of the decision suggests that there is a serious question as to whether the East Coast Model would have been treated as unlawful. Certainly, the East Model would have real difficulty in meeting the Dombo Beheer B.V. $v$ The Netherlands (1993) EHRR 213 test; the court said, at page 230:

The Court agrees with the Commission that as regards litigation involving opposing parties private interests, 'equality of arms' implies that each party must be afforded a reasonable opportunity to present his case including his evidence under conditions that do not place him at a substantial disadvantage visà-vis his opponent.

For the reasons set out in this paper, the East Coast Model would likely fail this test, but the West Coast Model would likely pass.

${ }_{59}$ Although s 24 of the Victorian Charter of Human Rights and Responsibilities Act 2006 contains the right to a fair hearing, which is in similar terms to Article 6 of the European Convention, upon which such a challenge could be attempted.

${ }^{60}$ If no such payment regime is provided for in the construction contract, then the payment provisions set out in Schedule 1 of the legislation are implied into the contract.

${ }^{61}$ le, the equivalent of a "payment schedule" in East Coast terminology. Although under the West Coast legislation a response to a payment claim is a contractual requirement rather than a statutory requirement.

62 le, the equivalent of the "respondent" in East Coast terminology.

${ }^{63}$ Within 14 days (WA Act, s 27(1)) or 10 working days (NT Act, s 29(1)) after the date on which a party to a construction contract is served with an application for adjudication.

${ }^{64}$ Which, in practice, means that an adjudicator under the East Coast legislation often makes a determination on documents only.
}

Coggins, J et al. (2010) 'Towards harmonisation of construction industry payment legislation: a consideration of the success afforded by the East and West Coast models in Australia', Australasian Journal of Construction Economics and Building, 10 (3) 14-35 
bound by the rules of evidence and may inform himself or herself in any way he or she thinks fit." 65 This has the effect of extending the adjudicator's investigative powers beyond the consideration of the parties' submissions, thus assisting the adjudicator in ascertaining the facts and the law.

It is submitted that this approach would seem far more likely to result in an outcome which is far more palatable to both parties to the dispute if not only for the perception of justice having been carried out. This submission is, perhaps, borne out in the small number of applications to the WA Supreme Court and State Administrative Tribunal to have an adjudicator's determination set aside (see section 6.3 below)

\section{Other Issues Affecting Justice}

The East Coast model does not permit the parties any legal representation (s 21(4A) of the NSW Act) at conferences called by the adjudicator. The West Coast model allows the adjudicator to determine his or her own adjudication procedure (s 32(6) of the WA Act), and does not specifically preclude legal representation at hearings. Thus, in WA and the NT legal representation at conferences is at the adjudicator's discretion.

Whilst the preclusion of legal representation contributes to keeping the costs of the adjudication process to a minimum, such preclusion may be detrimental to real and perceived substantive justice if it prevents the adjudicator from gaining a better understanding of the issues in dispute. This may particularly be so in disputes where the issues are of a complex nature, such as disputes regarding damages claims. In such disputes the barring of legal representation may, indeed, be a false economy if one of the parties subsequently pursues the dispute in litigation or arbitration due to a feeling of dissatisfaction with the way their case has been presented and/or understood in the adjudication process.

Under the East Coast model, the adjudication application must be made to an ANA chosen by the claimant (s 17(3) of the NSW Act). It is then the duty of the chosen ANA to refer the application to an adjudicator (s 17(6) of the NSW Act). The parties, therefore, cannot agree upon the appointment of a particular individual as adjudicator.

Under the West Coast model, the parties to the contract may agree upon a registered adjudicator or prescribed appointor (s 26(1)(c) of the WA Act). The provision to agree upon a particular individual as adjudicator may be significant to the disputing parties' feeling of perceived and real substantive justice. This is particularly so where the issues in dispute are of a complex nature and the parties would prefer the appointment of an adjudicator who they feel is suitably qualified and experienced, and in whom they have mutual confidence, to determine the dispute in hand within a restricted timeframe. It may, however, be argued that blind adjudicator appointment, as per the East Coast model, denies the opportunity for a party with dominant bargaining power to unfairly influence the identity of the adjudicator at the time of contract formation and thereby erode substantive justice. Notably, the NZ Act circumvents this issue by providing that any agreement about the choice of adjudicator or ANA/prescribed appointor is not binding if it was made before the dispute arose (s 33(3) of the NZ Act).

The East Coast model allows the Minister to authorise ANAs to nominate adjudicators for the purposes of the Act (s 28(1)(a) of the NSW Act). The adjudication application must be made to an ANA chosen by the claimant (s 17(3) of the NSW Act). Currently, nine ANAs are authorised in NSW, six of which are construction or legal professional bodies or

\footnotetext{
${ }^{65}$ See $s$ 32(1)(b) of the WA Act, and $s 34(1)(b)$ of the NT Act. Note that the NT Act substitutes the word "appropriate" for "fit" in this provision.

Coggins, J et al. (2010) 'Towards harmonisation of construction industry payment legislation: a consideration of the success afforded by the East and West Coast models in Australia', Australasian Journal of Construction Economics and Building, 10 (3) 14-35
} 
associations, and three of which are private for-profit companies. The West Coast model prescribes appointers of registered adjudicators in the regulations to the Act. Currently, the WA regulations list eight prescribed appointers, all of which are construction or legal professional bodies or associations. Generally, the professional bodies and associations provide nomination/appointment services as part of their service to the profession they represent. All appointing bodies under the East and West Coast models take a commission from the fee paid by the disputing parties to the adjudicator, either in the form of a lump sum or on a percentage basis.. The level of this commission widely varies between the different appointing bodies from $10 \%$ for some professional bodies to around $40 \%$ for some "for profit" companies (South Australian House of Assembly 2009: 4617) depending upon the level of services each provides to their adjudicators (overhead costs) and the profit margin (if any) each seeks to gain from appointing adjudicators. This raises a question as to whether adjudication outcomes are in any way affected by a claimant's choice of a particular appointing body, and particularly whether there is any correlation between the level of commissions appropriated from adjudicators' fees by appointing bodies and substantive outcomes of adjudications. There appears to be little, if any, research into this question to date.

Under the East Coast model, a claimant may take months to prepare a comprehensive and lengthy payment claim for delay damages for inclusion in a payment claim leaving the unsuspecting respondent only ten business days ${ }^{66}$ to respond in its payment schedule (s 14(4)(b)(ii) of the Act). By way of example, Davenport (2006: 147) refers to Contrax Plumbing, where the claimant contractor made a progress claim including an ambit claim for approximately $\$ 2$ million which took 12 months to prepare and was supported by two boxes of files detailing the claimant's allegations. A similar "ambush" claim may also occur under the West Coast model, which provides only a matter of weeks for a party to respond. ${ }^{67}$ This is clearly an unfair practice which inevitably results in both procedural and substantive injustice. A potential solution to the problem of ambush claims may be to amend the legislation so as to limit the length of written submissions in a similar manner to the UK legislation. ${ }^{68}$

\section{Administrative and Legal Burdens created by the Legislation}

Whilst the adjudication process in all Australian jurisdictions is proving to be a relatively low cost method of resolving payment disputes per se, ${ }^{69}$ the real costs to the construction industry of mandatory adjudication need to take account of any additional consequential administrative and legal costs. The statutory payment system operated by the East Coast model inevitably creates extra administrative workload, above and beyond normal contract administration duties, for parties on a construction contract. This is not the case under the West Coast model, which allows primacy of the contractually agreed payment system.

\section{Preparation of Payment Claims}

Under the East Coast legislation, a payment claim must, amongst other things, identify the construction work or related services to which the progress payment relates (s 13(2) of the NSW Act). Accordingly, the relevant construction work has to be identified "sufficiently to

\footnotetext{
${ }^{66}$ Or, as noted above, 15 business days in the case of the SA Act.

${ }^{67}$ If nothing is stated in the construction contract, a party is given 14 days to respond to a payment claim under Schedule 1, Division 5 of the WA Act. A claimant must then apply for adjudication within 28 days after the dispute has arisen (see s 26(1) of the WA Act). A party who is served with an adjudication application then has 14 days to prepare and serve a written response to the adjudication application (see s 27(1) of the WA Act).

68 See Part I, s 13(g) of the UK Scheme for Construction Contracts.

${ }^{69}$ Mean adjudication fees in WA reported by the Construction Contracts Registrar (2009) for the year ended 30 June 2009 range between $\$ 1364$ (for claims below $\$ 10,000$ ) to $\$ 6065$ (for claims above $\$ 500 k$ ). Mean adjudication fees in Queensland reported by the Building and Construction Industry Payments Agency (2009) range between $\$ 919$ (for claims below $\$ 10,000$ ) to $\$ 16,324$ (for claims above $\$ 500 \mathrm{k}$ ).
}

Coggins, J et al. (2010) 'Towards harmonisation of construction industry payment legislation: a consideration of the success afforded by the East and West Coast models in Australia', Australasian Journal of Construction Economics and Building, 10 (3) 14-35 
enable the respondent to understand the basis of the claim". ${ }^{70}$ This is "a relatively undemanding test". ${ }^{71}$ However, in Protectavale Pty Ltd v K2K Pty Ltd ${ }^{72}$ the court held that a payment claim needs to identify which work has already been paid for (the 'Protectavale principle'). ${ }^{73}$ This may present a real problem for a claimant where, as is common on construction contracts, the contractual basis for a claim is the total value of construction works completed minus payments to date, and the claimant is not able to identify what has been paid for and what has not. This is particularly so if the previous payments by the respondent are vague as to what is being paid for, and the numbers cannot be readily reconciled with previous claims.

The Protectavale principle, therefore, has the potential to create an administratively complex task for claimants who need to ensure they keep track of which specific items of construction works have previously been paid for. This is a task which may be made especially difficult in the face of a canny respondent who is carefully trying to make it impossible for a claimant to know precisely how much it is paying for which item. ${ }^{74}$ Additionally, the application of the Protectavale principle means that, in a situation where a respondent has been able to successfully "muddy the waters" with respect to which items have been paid for, procedural and substantive justice may be denied to a claimant.

\section{Preparation of Payment Schedules}

It is suggested that the requirement for the respondent to prepare comprehensive payment schedules, in order to preserve its right to put forward the merits of its argument, is practicably too onerous. As one of us has noted (Fenwick Elliott 2007: 3), this feature of the NSW Act:

sets up tens of thousands of procedural traps (one for every payment claim that is received) and if head contractors or principals fail to divert sufficient resources to the massive task of preparing the appropriate payment schedules, a claiming contractor or subcontractor is entitled to obtain a more or less default adjudication decision.

It would be hard to exaggerate the importance and the difficulty of providing payment schedules to every single payment claim that comes in to an office. A typical head contractor will receive a large number of payment claims each month, and it is extremely common for head contractors to fail to keep on top of the paperwork required by the legislation.

Furthermore, if a respondent rejects a payment claim in a payment schedule, this does not prevent a tenacious claimant from making the same claim month after month. As noted by the NSW Department of Public Works and Services (2002: 21):

A vexatious claimant may serve the same payment claim repeatedly over a period of time, with the hope that the respondent will eventually fail to serve a payment schedule. The claimant could then recover the full amount of the claim through court under $\mathrm{s} 15$ of the Act.

\footnotetext{
${ }^{70}$ Coordinated Construction Co Pty Ltd v Climatech (Canberra) Pty Ltd [2005] NSWCA 229 at [25].

${ }_{71}^{71}$ Nepean Engineering Pty. Ltd. v. Total Process Services Pty. Ltd. (In Liquidation) [2005] NSWCA 409 at [48].

72 [2008] FCA 1248 (a Victorian Case).

73 The 'Protectavale principle' was also applied in Queensland in Neumann Contractors P/L $v$ Peet Beachton Syndicate Limited [2009] QSC 376.

${ }^{74}$ For instance, it is not a requirement of a payment schedule that a respondent breaks down the amount that he proposes to pay amongst all of the items claimed. Thus, provided the respondent identifies which items he is not paying for in full, and says why he is not paying for them in full, he can still comply with the Act without telling the claimant party precisely how much he is prepared to pay in respect of which item.
}

Coggins, J et al. (2010) 'Towards harmonisation of construction industry payment legislation: a consideration of the success afforded by the East and West Coast models in Australia', Australasian Journal of Construction Economics and Building, 10 (3) 14-35 
Therefore, a respondent may have to defend the same payment claim on several occasions throughout the duration of the construction contract, spelling out all of the reasons on each occasion. $^{75}$

\section{Volume of Litigation and Clarity of the Law}

As previously referred to, there have been at least 210 NSW Supreme Court judgments, and 41 NSW Court of Appeal judgments, in relation to issues concerning the NSW Act since 2001. The majority of these judgments represent cases where a respondent has attempted to have an adjudicator's determination, or part thereof, set aside.

\section{Principal Issue before the Court}

No. of Cases

Whether payment claim (in full or in part) is valid ${ }^{16}$

Whether a construction contract or arrangement within scope of Act exists"

Whether plaintiff was denied natural justice and/or adjudicator failed to make a bona fide attempt to exercise his/her task under the Act ${ }^{18}$

Whether, under the Corporations Act a genuine dispute exists for an off-setting claim against the adjudicated amount which the claimant is trying to enforce by statutory demand ${ }^{79}$

Whether there has been an abuse of the processes under the Act $^{80}$

Whether adjudicator correctly applied s 34 of the Act to include sums in the adjudicated amount over and beyond an agreed sum in the contract ${ }^{81}$

Whether adjudicated amount should be corrected $^{82}$

Whether adjudicator was validly appointed ${ }^{83}$

Whether damages claimed in adjudication application outside of scope of payment claim $^{84}$

Whether reasons for withholding payment can be incorporated by reference into the payment schedule ${ }^{85}$

Whether payment schedule can be provided by an agent of the respondent ${ }^{86}$

Total

Table 1 Judgments of the NSW Supreme Court in 2009 with respect to applications challenging payment of adjudicated amount

Ten years on from the commencement of the NSW Act, the numbers of such applications show little signs of abatement, with at least $21^{87}$ related judgments coming out of the NSW

\footnotetext{
${ }^{75}$ Although, note that in Perform (NSW) Pty Ltd v MEV-AUS Pty Ltd \& Anor [2009] NSWCA 157, the NSW Court of Appeal held that a payment schedule could indicate reasons for nil valuation by referring to previous payment schedule.

76 The Owners Strata Plan 56587 v Consolidated Quality Projects [2009] NSWSC 1476 ; Allpro Building Services v C\&V Engineering Services [2009] NSWSC 1247; Urban Traders v Paul Michael [2009] NSWSC 1072; The University of Sydney v Cadence Australia Pty Limited \& Anor [2009] NSWSC 635; Perform (NSW) Pty Ltd v MevAus Pty Ltd trading as Novatec Construction Systems [2009] NSWSC 416.

77 Parkview v Fortia [2009] NSWSC 1065; Cardiacos v Cooper Consulting \& Construction Services (Aust) Pty Ltd [2009] NSWSC 938; Levadetes v Iberian Artisans [2009] NSWSC 641; Olbourne v Excell Building Corp Pty Limited [2009] NSWSC 349; Duynstee v Dickens \& Dickens [2009] NSWSC 292.

${ }_{78}$ Robson Civil Projects Pty Limited v Walter Mining Pty Limited [2009] NSWSC 1071; Reid v Eire [2009] NSWSC 678.

${ }_{79}$ Project v TQM [2009] NSWSC 699; Diddy Boy v Design [2009] NSWSC 14.

${ }^{80}$ Filadelfia Projects Pty Limited v EntirlTy Business Services Pty Limited [2009] NSWSC 1468.

${ }^{81}$ Roseville Bridge Marina Pty Ltd v Bellingham Marine Australia Pty Ltd [2009] NSWSC 320.

82 Holdmark v Melhemcorp [2009] NSWSC 305.

83 Kittu Randhawa v Monica Benavides Serrato [2009] NSWSC 90.

84 Parkview Constructions Pty Ltd v Sydney Civil Excavations Pty Ltd \& anor [2009] NSWSC 61.

${ }^{85}$ Perform (NSW) Pty Ltd v Mev-Aus Pty Ltd trading as Novatec Construction Systems [2009] NSWSC 416.

${ }^{86}$ Lucas Stuart v Hemmes Hermitage [2009] NSWSC 477.
}

Coggins, J et al. (2010) 'Towards harmonisation of construction industry payment legislation: a consideration of the success afforded by the East and West Coast models in Australia', Australasian Journal of Construction Economics and Building, 10 (3) 14-35 
Supreme Court in 2009. ${ }^{88}$ All of these 2009 cases for one reason or another (see Table 1 below) sought to challenge the payment of an amount determined in adjudication.

By any measure, this is a significant amount of litigation. Furthermore, this does not include cases where, dissatisfied with the outcome of adjudication, a respondent has subsequently applied to court or arbitration to have the payment dispute finally determined. ${ }^{89}$ This compares with a total of three WA Supreme Court judgments (and no WA Court of Appeal judgments) in relation to issues concerning the WA Act since its enactment in 2004, only one ${ }^{90}$ of which concerned an application to have the adjudicator's determination set aside. ${ }^{91}$ Such diversity in the amount of litigation generated by the NSW and WA legislation may, perhaps, be reflective of respondents' level of dissatisfaction, and consequent lack of willingness to accept the adjudicator's decision, with the substantive and procedural justice afforded by each of the two models.

Additionally, the significant body of NSW case law generated by the Act may be reflective of a lack of clarity with respect to the legislative drafting leaving many issues to be interpreted and given certainty by the judiciary. Hence, there has been, and still appears to be, the potential for respondents to argue that an adjudicator's determination should be set aside on the basis of several issues. These include issues relating to delay damages, grounds for reviewability of an adjudicator's determination, ${ }^{92}$ payment claim reagitation or issue estoppel, ${ }^{93}$ information to be included on a duly submitted payment claim (Protectavale Pty Ltd $v$ K2K Pty Ltd [2008] FCA 1248), the scope of section 34 of the Act with respect to voiding contractual provisions which restrict the operation of the Act, ${ }^{94}$ and conflict between the Act and Federal corporations and trade practices law. ${ }^{95}$

\section{Conclusion}

A successful dispute resolution process is one that is sustainable in the context of the industry in which it operates. To be sustainable, the procedure and outcomes of a dispute resolution process need to satisfy the dispute stakeholders in order to achieve efficiency (in terms of time and cost) and finality. The real and/or perceived justice afforded by the dispute resolution process is a key factor in stakeholder satisfaction. Furthermore, an adequate

87 This figure was obtained by conducting a search on the NSW Lawlink Case Law website $<$ http//:www.lawlink.nsw.gov.au/lawlink/caselaw/ll_caselaw.nsf/cases/cl_sc > using the keywords "Building and Construction Industry Security of Payment Act". The figure is indicative and not necessarily a fully accurate number of the total judgments in 2009.

${ }^{88}$ Additionally, at least four judgments were made by the NSW Court of Appeal in 2009 in relation to issues concerning the NSW Act.

${ }^{89}$ No existing data in this respect could be found.

90 O'Donnell Griffin Pty Ltd v John Holland Pty Ltd [2009] WASC 19 where the plaintiff applied for a writ of certiorari to quash the adjudicator's determination.

N1 Note that a search on the WA State Administrative Tribunal (SAT) decisions database website $<$ http://decisions.justice.wa.gov.au/SAT/SATdcsn.nsf> revealed that there have been 34 SAT judgments since the enactment of the WA Act in 2004. However, most of these judgments concern a review of an adjudicator's decision to dismiss an adjudication application without making a determination of its merits (see $s 31$ (2)(a) \& $s$ 46(1) of the WA Act). SAT has made it clear it will only review adjudicators' decisions with respect to jurisdiction, and that it will not review an adjudicator's determination on the merits - for example, see Match Projects Pty Ltd and Arcon (WA) Pty Ltd [2009] WASAT 134.

${ }^{92}$ Musico \& Ors v Davenport \& Ors [2003] NSWSC 977; Brodyn Pty Limited T/as Time Cost and Quality v Davenport \& Anor [2004] NSWCA 394; Holmwood Holdings v Halkat Electrical Contractors \& Anor [2005] NSWSC 1129.

${ }^{93}$ See Dualcorp Pty Ltd v Remo Constructions Pty Ltd [2009] NSWCA 69; Urban Traders v Paul Michael [2009] NSWSC 1072; and Filadelfia Projects Pty Limited v EntirlTy Business Services Pty Limited [2009] NSWSC 1468.

${ }^{94}$ See Minister for Commerce $v$ Contrax Plumbing [2004] NSWCA 142; John Goss Projects $v$ Leighton Contractors Pty Ltd \& Davenport [2006] NSWSC 798; John Holland Pty Ltd $v$ Roads and Traffic Authority of New South Wales[2006] NSWSC 874.

${ }^{95}$ See Greenaways Australia Pty Ltd v CBC Management Pty Ltd [2004] NSWSC 1186; Aldoga Aluminium Pty Limited v De Silvia Starr PTY Limited [2005] NSWSC 284; Bitannia Pty Ltd v Parkline Constructions Pty Ltd [2006] NSWCA 238.

Coggins, J et al. (2010) 'Towards harmonisation of construction industry payment legislation: a consideration of the success afforded by the East and West Coast models in Australia', Australasian Journal of Construction Economics and Building, 10 (3) 14-35 
opportunity for disputants to be heard and a belief that any third party tribunal has acted fairly in determining the dispute have been found to be important components of real and perceived justice.

Accordingly, a successful construction industry payments legislative scheme needs to not only facilitate as far as possible the flow of cash down the contractual chain in an expedient manner, but be able to sustain such improved cash flow for all parties across the whole construction industry by maximising real and perceived justice of the scheme, minimising overall costs to the construction industry of settling payment disputes, and encouraging positive relationships between the contracting parties.

Whilst the numbers of adjudication applications in the East Coast model jurisdictions have progressively increased to a high level since commencement of the legislation, and adjudication fees have been consistently low, it would appear that the legislation generates significant consequential administrative and legal burdens upon the construction industry. This is particularly evinced in the considerable resources needed by principals to prepare potentially numerous comprehensive payment schedules in each payment period and the vast amount of litigation in the NSW courts initiated by disgruntled respondents in an attempt to have adjudication determinations set aside.

It is suggested that such administrative and legal burdens can be directly related to the lack of procedural and substantive justice afforded by the East Coast legislation, particularly as a result of the restrictions the legislation places on the rights of respondents to present their case in adjudication responses and the adjudicator to ascertain the facts and law beyond what is contained in the parties' submissions. Additionally, several issues arising from the legislative provisions have required judicial interpretation, creating both: opportunity for unhappy respondents to argue in court that an adjudicator's determination should be set aside; and, a lack of legal clarity for stakeholders regarding the use of the legislation.

There have been substantially fewer applications to the courts in WA to have adjudicators' determinations set aside. Additionally, as the West Coast legislation gives primacy to any contractual interim payment scheme agreed by the parties, it does not generate the extra administrative burden associated with the East Coast model's dual payment system. Further, as the West Coast legislation places no restrictions on the right of either disputing party to present its case in adjudication, and the adjudicator may inform himself or herself about the dispute in any way he or she thinks fit, it is proposed that the West Coast model affords higher levels of procedural and substantive justice than the East Coast model.

This paper is principally concerned with the Australian experience. Nevertheless, it is useful to compare the Australian experience with the experience overseas, and in particular that of the UK and NZ.

The UK Model is even more evaluative than the West Coast model, in that the adjudicators are under a duty to exercise their initiative to ascertain the facts and the law. Before the UK legislation was passed by the Housing Grants, Construction and Regeneration Act 1996, the construction industry there was (per Latham 1993) suffering badly from a lack of trust engendered by the ability of paymasters to delay or evade payment with relative impunity. Since that legislation was implemented, there has been a considerable improvement, and all parties (including, importantly, head contractors) appear to regard adjudicators' decisions as generally fair, and the industry has benefited from much more balanced and productive relationships between contracting parties. Parties who have been through adjudications inter se have often moved on rapidly to an enhanced working relationship. Conversely, anecdotal evidence suggests that East Coast model adjudications are not typically perceived by both

Coggins, J et al. (2010) 'Towards harmonisation of construction industry payment legislation: a consideration of the success afforded by the East and West Coast models in Australia', Australasian Journal of Construction Economics and Building, 10 (3) 14-35 
parties as fair, and often lead to a total breakdown of the commercial relationship between the adjudicating parties.

Whilst it is hoped the observations and propositions made by the authors in this article will provide a useful platform for debate and further discussion, it is recognised that little work has been done to canvass the opinions of the legislation's stakeholders across Australia with respect to levels of satisfaction with the various Acts. There is a need for such a nationwide survey before any firm recommendations can start to be formed as to the most appropriate conceptual framework and detail to be adopted in any harmonised model. As such, the recently conducted survey by the Society of Construction Law Australia, ${ }^{96}$ calling for submissions and views from its members in relation to the current security of payment legislative framework and potential avenues for reform, is a step in the right direction.

\section{Addendum}

Since the preparation of this paper, the Court of Appeal in New South Wales has handed down its decision in Chase Oyster Bar v Hamo Industries ${ }^{97}$, in which it was decided that adjudication decisions in New South Wales are susceptible to court review by way of certiorari, and that the limits for court review are not set by the five "basic and essential requirements" identified in Brodyn $v$ Davenport. Although the court did not dwell on the point, it seems that such certiorari challenge is not limited to challenge on the grounds of want of jurisdiction, and indeed Spigelman CJ found that the fatal defect in this case - a failure by the claimant to give notice of intention to apply for adjudication within 20 days of the due date for payment as required by section 17(2) of the NSW Act - was not a jurisdictional matter. And so perhaps challenges will be available on the other certiorari grounds ${ }^{98}$. It was also found that the court is not bound by findings of the adjudicator as to jurisdictional matters.

In Victoria, the courts had come to a similar view as to the availability of certiorari ${ }^{99}$, but subject to the view that it would not disturb adjudicators' findings as to jurisdictional issues. The numbers of Victorian adjudications remain low, and the impact of certiorari there has been correspondingly slight. In Western Australia, the courts have held that certiorari is excluded by the terms of the WA Act.

It remains to be seen what impact the Chase Oyster Bar case will have on security of payment cases. It appears to represent some turning of the judicial tide away from the legislative objective of a quick and enforceable process. Potentially, many East Coast adjudications might now be susceptible to challenge on the basis of error on the face of the record, and this may represent a further point of distinction from its West Coast cousin.

\section{References}

Bailey. I. (2009) Harmonisation or Reform of Legislation: Construction Industry and Dispute Resolution, Paper delivered at Construction Law Seminar, Melbourne Law School, 10 November 2009

Bell, M. and Vella, D. (2010) 'From motley patchwork to security blanket: The challenge of national uniformity in Australian 'security of payment' legislation', Australian Law Journal, 84, 565

\footnotetext{
96 The survey is being administered by the Australian Legislation Reform Sub-Committee - see http://scl.org.au/sop-survey/

97 [2010] NSWCA 190

${ }^{98}$ Including it seems error on the face of the record; per Basten $\mathrm{J}$ at paragraph 91.

${ }^{99}$ See Hickory Developments v Schiavello [21009] VSC 156 and Grocon v Planit (No 2) [2009] VSC 426.
}

Coggins, J et al. (2010) 'Towards harmonisation of construction industry payment legislation: a consideration of the success afforded by the East and West Coast models in Australia', Australasian Journal of Construction Economics and Building, 10 (3) 14-35 
Bingham, L.B. (1997) 'Employment Arbitration: The Repeat Player Effect', Employee Rights and Employment Policy Journal, 1, 189

Bingham, L.B. (2008) 'Designing Justice: Legal Institutions and Other Systems for Managing Conflict', Ohio State Journal on Dispute Resolution, 24, 1

Brand, M.C. and Uher, T. (2010) 'Follow-up empirical study of the performance of the New South Wales construction industry security of payment legislation', International Journal of Law in the Built Environment, 2,1

Building \& Construction Industry Payments Agency (2009) 'Annual Report 2008-09', BCIPA website, viewed on 20 April 2010,

$<$ http://www.bcipa.qld.gov.au/SiteCollectionDocuments/Publications/Annual\%20Report\%200 8009.pdf>.

Building \& Construction Industry Payments Agency (2010) 'Adjudication Statistics - April 2010 Report', BCIPA website, viewed on 20 April 2010,

$<\mathrm{http} / /$ :www.bcipa.qld.gov.au/Reports/Pages/Reports.aspx>

Coggins, J, (2009) 'A Review of Statutory Adjudication in the Australian Building and Construction Industry, and a Proposal for a National Approach', Proceedings of the Construction and Building Research Conference of the Royal Institution of Chartered Surveyors (COBRA 2009), Cape Town

Cole, T.R.H. (2003) Final Report of the Royal Commission into the Building and Construction Industry, Commonwealth of Australia, February 2003

Constable, A. (2006) 'Construction industry payment and adjudication legislation: the choice that lies ahead for Malaysia', International Construction Law Review 78, 80

Constantino, C.A. and Sickles Merchant, C. (1996) Designing Conflict Management Systems, A Guide to Creating Productive and Healthy Organizations, Jossey-Bass Publishers, San Francisco

Construction Contracts Registrar (2009) Report of the Construction Contracts Registrar for the year ended 30 June 2009, WA Building Industry Development website, viewed on 20 April 2010, <http://www.buildingcommission.wa.gov.au/bid/Annual_Reports_BID.aspx>

Coulson, P. (2007) Construction Adjudication, Oxford University Press.

Davenport, P. (2004) Adjudication in the Building Industry, $2^{\text {nd }}$ ed, Federation Press, Annandale, NSW

Davenport, P. (2006) Construction Claims, $2^{\text {nd }}$ ed, Federation Press, Annandale, NSW

Davenport, P. (2007) 'A Proposal for a Dual Process of Adjudication', Australian Construction Law Newsletter, 115, 12-24

Davenport, P. (2010) 'Security of payment now Australia wide'131 Australian Construction Law Newsletter, 36

De Cremer, D. and van Knippenberg, D. (2003) 'Cooperation with leaders in social dilemmas: on the effects of procedural fairness and outcome favourability in structural cooperation', Organizational Behaviour and Human Decision Processes, 91, 1-11

Fenwick Elliott, R. (2007) '10 Days in Utopia', Proceedings of the Institute of Arbitrators \& Mediators Australia, Glenelg, South Australia

Jacobs, M.S. (2010) Security of Payment in the Australian Building and Construction Industry, $3^{\text {rd }}$ ed, Thomson Reuters, Pyrmont, NSW

Latham, M. (1993) Trust and Money: the Interim Report of the Joint Government/Industry Review of Procurement and Contractual Arrangements in the United Kingdom Construction Industry, HMSO, London

Lloyd, H. (2001) 'Adjudication', International Construction Law Review 437

Coggins, J et al. (2010) 'Towards harmonisation of construction industry payment legislation: a consideration of the success afforded by the East and West Coast models in Australia', Australasian Journal of Construction Economics and Building, 10 (3) 14-35 
NSW Department of Public Works and Services (2002) 'Review Discussion Paper - Options for Enhancing the Building and Construction Industry Security of Payment Act 1999', available at <http://ableadjudication.com.au/wp-content/uploads/2010/02/sop-discussionpaper-200209.pdf>

NSW Procurement (2009) Building and Construction Industry Security of Payment Act 1999 Fact Sheet, obtained by request from the NSW Department of Commerce

O'Reilly, S. and Stankiewicz, L. (2006) 'Unique overhaul of security of payment in Victoria', Clayton Utz Projects Insights, 16 August 2006

Redenbach, K. (2007), 'Getting paid in the construction industry - national perspective' 23 Building and Construction Law Journal 92

Riddell, R. (2009) 'The Cases for and Against Harmonisation of Security of Payment Regimes in Australia', Proceedings of the Institute of Arbitrators and Mediators Australia National Conference, Melbourne

Ridley, S. (2006) 'Security of payment changes continue in Victoria', 18(7) Australian Construction Law Bulletin 81.

South Australian House of Assembly (2009) Hansard, 29 October 2009, viewed on 30 April 2010,

<http://hansard.parliament.sa.gov.au/docloader/House\%20of\%20Assembly/2009_10_29/Dai ly/House\%20of\%20Assembly_C_Daily_DIST_2009_10_29_v5.pdf>

Susskind, L. and Cruikshank, J. (1987) Breaking the Impasse: Consequential Approaches to Resolving Public Disputes, Basic Books, New York

Tyler, T.R. (2000) 'Social justice: outcome and procedure', International Journal of Psychology, 35, 117-125.

Ury, W. Brett, J.M. and Goldberg, S.B. (1988) Getting disputes resolved: designing systems to cut the cost of conflict, Jossey-Bass Publishers, San Francisco

Van Veen, D.H., Kreutzwiser, R.D. and de Loë, R.C. (2003) 'Selecting appropriate dispute resolution techniques: a rural water management example', Applied Geography, 23, 89-113

Warren, E. and Thwaites, A. (2007) 'Amendments to the Victorian security of payment regime underway', Allens Arthur Robinson Client Update, 8 May 2007

Zhang, T. (2009) 'Why national legislation is required for the effective operation of the security of payment scheme', Building and Construction Law Journal, 25, 376 